\title{
PERSEPSI KUALITAS MAHASISWA PROGRAM STUDI D III AKUNTANSI POLINES SELAMA PRAKTEK KERJA LAPANGAN (PKL) DI INDUSTRI
}

\author{
Moh.Hasanudin Marliyati, Sri Murtini, Ch. Retno G, Resi \\ Yudhaningsih \\ Jurusan Akuntansi Politeknik Negeri Semarang \\ muhammadhasanudin1976s@gmail.com
}

\begin{abstract}
This research aimed at exploring the quality of accounting diploma students during their internship program in industries. The term of student's quality described in this research isexplained using 5 main components as follows: (1) communication skills (2) teamwork (3) independence (4) creativity (5) accounting and information technology (IT)-related skills. The research's sample is industries where students of Diploma in Accounting of State Polytechnic of Semarang (SPS) took their intership and the students themselves whom have completed their internship program for three months in various institutions such as private enterprises, state owned enterprises, local government offices spread out around Central Java. The data on this research is time series data taken from 2015 to 2016 and was collected using questionnaires from the corresponding industries about the students competencies both hard skills and soft skills. Data was scored using Likert scale, ranges from Poor (1) to Excellent (5) and analyzed using statistic descriptive. The result showed that average students' quality during their internship was good. Among the 5 skills observed, the corresponding industries ranked teamwork skills as the highest, followed by independence, creativity, communication skills and the accounting and IT-related skills. It is expected that the result can be used for future development of Accounting Program Study of SPS.
\end{abstract}

Keywords: industry, skills, students, quality, internship

Abstrak: Penelitian ini bertujuan untuk menganalisis respon industri terhadap kemampuan mahasiswa Program Studi D III Akuntansi Politeknik Negeri Semarang, selama mereka melaksanakan Praktek Kerja Lapangan (PKL). Kemampuan mahasiswa diukur dengan menggunakan lima kelompok kompetensi yaitu (1) kemampuan berkomunikasi (2) kemampuan bekerjasama (teamwork) (3) kemandirian (4) kreatifitas (5) kemampuan dasar akuntansi dan penguasaan teknologi informasi. Sampel penelitian ini adalah industri tempat pelaksanaan PKL mahasiswa yang terdiri atas perusahaan swasta, instansi pemerintah/pemerintah daerah, Perbankan, Badan Usaha Milik Negara (BUMN), dan Badan Usaha Milik Daerah (BUMD) yang tersebar di wilayah Jawa Tengah. Data yang digunakan dalam penelitian ini adalah data berkelanjutan dari tahun 2015-2016 yang dikumpulkan dengan menggunakan kuesioner yang berisi sejumlah pertanyaan yang diajukan kepada industri responden untuk mengukur kemampuan hardskills dan softskills mahasiswa. Data diukur dengan menggunakan skala likert dengan rentang nilai mulai dari Sangat Baik (5) hingga Sangat Kurang (1) dan diolah dengan menggunakan statistik deskriptif. Hasil penelitian menunjukkan bahwa secara rata-rata kemampuan mahasiswa akuntansi selama melaksanakan PKL adalah baik. Dari lima kelompok kemampuan yang diuji, industri meranking kemampuan bekerjasama (teamwork), sebagai kemampuan yang paling tinggi, diikuti dengan kemandirian, kreatifitas, kemampuan berkomunikasi dan kemampuan akuntansi dasar dan penguasaan teknologi informasi. Hasil penelitian ini diharapkan 
dapat menjadi bahan masukan bagi pengembangan Jurusan Akuntansi Politeknik Negeri Semarang di masa datang.

Kata Kunci: industri, kemampuan, mahasiswa, kualitas, PKL

\section{PENDAHULUAN}

Magang merupakan salah satu bentuk pendidikan dan pelatihan yang akan membentuk kompetensi peserta didik. National training board Australia (1995) dalam Anonim (2008) mendeskripsikan bahwa Competency based Educational and Training (CBET) adalah pendidikan dan pelatihan yang menitikberatkan pada penguasaan suatu pengetahuan dan keterampilan khusus serta penerapannya di lapangan kerja. Pengetahuan dan keterampilan ini harus dapat didemonstrasikan dengan standar industri yang ada, bukan standar relatif yang ditentukan oleh keberhasilan seseorang di dalam suatu kelompok.

Sejalan dengan apa yang diamanatkan dalam Undang-Undang No. 12 Tahun 2012 , pasal 16 ayat 1 tentang pergurun tinggi yang menyatakan bahwa pendidikan vokasi merupakan pendidikan tinggi program diploma yang menyiapkan mahasiswa untuk pekerjaan dengan keahlian tertentu sampai dengan program sarjana terapan, maka Jurusan Akuntansi Politeknik Negeri Semarang menyelenggarakan pendidikan vokasi program D III Akuntansi. Salah satu tujuan program studi D III Akuntansi Polines adalah menghasilkan lulusan yang memenuhi standar kompetensi akuntansi dan berwawasan internasional yang kompetitif, kreatif, inovatif serta berkarakter kewirausahaan sesuai dengan kebutuhan masyarakat dan dunia industri. Disamping memiliki kompetensi utama tersebut, program studi juga membekali mahasiswa dengan nilai-nilai sofskills seperti kemampuan komunikasi, kerjasama tim, enterpreneurship, integritas diri, serta etika dan moral, sehingga lulusan benar-benar siap dalam memasuki dunia kerja.

Jurusan akuntansi telah merancang struktur kurikulum pendidikan Program Studi D III Akuntansi sedemikian rupa, sehingga tujuan program studi untuk dapat menghasilkan lulusan yang memiliki kompetensi sesuai dengan kebutuhan industri dapat tercapai.Salah satu mata kuliah wajib yang menunjang tercapainya tujuan ini adalah Praktek Kerja Lapangan (PKL). PKL pada Program Studi D III Akuntansi dilaksanakan pada semester 5 (lima) selama 3 (tiga) bulan. Dalam jangka waktu yang cukup panjang tersebut kegiatan PKL ini diharapkan dapat menjadi salah satu sarana bagi mahasiswa untuk mengasah kemampuan hardskill dan sofskill mereka dalam lingkungan kerja yang sesungguhnya, sebagaimana yang disampaikan oleh Wijanarka (2012) bahwa unjuk kerja calon tenaga kerja yang dibutuhkan oleh dunia kerja selalu berubah sesuai dengan kemajuan ilmu pengetahuan dan teknologi begitu juga dengan softskills, berwujud karakter tenaga kerja.

Keterlibatan industri dalam pendidikan vokasi dinilai memiliki peran penting karena pendidikan vokasi harus melibatkan industri (Murnomo, 2010), sehingga institusi dapat mengetahui sejauh mana kesiapan lulusan untuk diserap oleh dunia kerja.Sebagai umpan balik dan masukan bagi Jurusan Akuntansi Polines terhadap kemampuan calon lulusan di dunia kerja, Jurusan Akuntansi mewajibkan mahasiswa yang melaksanakan PKL untuk membawa kuesioner yang akan diisi oleh industri tempat PKL mereka terkait dengan kemampuan mahasiswa tersebut. Dengan adanya penilaian dari dunia industri ini, 
Jurusan Akuntansi Polines dapat mengukur sejauh mana kualitas atau kemampuan yang telah dimiliki oleh calon lulusan mereka atau kekurangan yang masih harus diperbaiki dan ditingkatkan dimasa yang akan datang.

\section{TINJAUAN PUSTAKA Persepsi}

Persepsi merupakan proses yang berlangsung pada diri kita untuk mengetahui dan mengevaluasi orang lain. Dengan proses itu, kita membentuk kesan tentang orang lain. Kesan yang kita bentuk di dasarkan pada pada informasi yang tersedia di lingkungan, sikap kita terdahulu tentang rangsanganrangsangan yang relevan. (Bagus takwin) Berikut ini beberapa pengertian persepsi :

"Persepsi menurut Kamus Besar Bahasa Indonesia (KBBI) adalah tanggapan (penerimaan) langsung dari sesuatu atau proses seseorang mengetahui beberapa hal melalui panca inderanya".

Menurut M.Alisuf Sabri bahwa persepsi atau tanggapan adalah sesuatu yang pernah kita amati/alami selalu tertinggal jejaknya atau kesannya di dalam jiwa kita. Hal itu dimungkinkan oleh kesanggupan chemis dari jiwa kita. Bekas jejak/kesan yang tertinggal pada kita itu dapat kita timbulkan kembali (reproduksi) sebagai tanggapan.

\section{Kemampuan Komunikasi}

Komunikasi adalah suatu proses pertukaran informasi antar individu melalui suatu sistem yang biasa, baik dengan simbol-simbol, sinyal-sinyal, maupun perilaku atau tindakan (Purwanto, 2006). Sementara itu menurut Bovee and John (2007) komunikasi adalah proses mengirimkan dan menerima pesan. Proses komunikasi dimulai dari pengirim mempunyai pesan, menyandikan pesan, mengirim pesan, memahami pesan, penerima mengartikan pesan, dan mengirimkan umpan balik.
Komunikasi dapat dilakukan melalui bentuk lisan maupun tulisan dengan menggunakan berbagai media untuk menyampaikan pesan.

$\begin{array}{lrr} & \text { Kemampuan } & \text { komunikasi } \\ \text { sangat penting } & \text { dalam } \\ \text { mempersiapkan diri } & \text { untuk }\end{array}$
memasuki dunia kerja. Sebagai calon tenaga kerja professional, kemampuan komunikasi ini menjadi salah satu faktor penentu kesuksesan dalam bekerja karena dengan komunikasi yang baik seorang bisa berinteraksi baik dengan internal maupun eksternal (Republika online, 2013). Kemampuan komunikasi diperlukan untuk dapat menyampaikan informasi, mengkomunikasikan ide, atau memahami surat-surat bisnis dengan efektif melalui berbagai saluran dan media komunikasi, secara lisan dan tulisan, baik dengan bahasa Indonesia maupun bahasa Inggris sehingga dapat meminimalkan hambatan yang akan terjadi selama proses komunikasi berlangsung.

\section{Kerjasama}

Pengertian kerjasama dalam Kamus Besar Bahasa Indonesia adalah kegiatan atau usaha yang dilakukan beberapa orang (lembaga atau pemerintah dan seterusnya) untuk mencapai tujuan bersama. Kerjasama juga berarti interaksi sosial antar individu atau kelompok yang secara bersama-sama mewujudkan kegiatan untuk mencapai tujuan bersama. Dalam suatu kelompok atau dunia usaha/industri, perusahaan diharapkan dapat bersaing secara global, memenuhi standar yang lebih tinggi dan mencapai laba yang maksimum. Agar dapat memenuhi tujuan tersebut, organisasi pun mulai membentuk kelompok dan kerjasama tim dengan alasan-alasan untuk (1) mendapatkan keputusan yang lebih baik, (2) mendapatkan respon yang lebih cepat dalam pemecahan masalah, (3) meningkatkan produktifitas, (4) resistensi yang 
rendah terhadap perubahan (Guffey, et.al, 2005).

\section{Kemandirian}

Pengertian kemandirian menurut Kamus Besar Bahasa Indonesia adalah hal atau keadaan dapat berdiri sendiri tanpa bergantung pada orang lain. Dalam praktik industri maupun di dunia kerja nantinya, kemandirian sangat diperlukan oleh seorang karyawan. Pengetahuan tentang suatu bidang saja tidak cukup, tanpa diiringi dengan kemandirian dalam memecahkan permasalahan yang dihadapi, rasa percaya diri dan menjalankan tugas tanpa adanya pengawasan dari penyelia atau supervisor.

$$
\text { Menurut Lilik (2008), }
$$
seorang karyawan tidak hanya bertumpu pada kecerdasan kognitif mutlak, akan tetapi lebih luas dan fleksibel atau dengan kata lain, kondisi tertentu dengan kemandirian yang dimiliki akan mampu menyelesaikan, merespons tugastugas tertentu yang mungkin harus diputuskan sendiri dan dilakukan sendiri dengan tanggungjawabnya. Kemandirian atau dengan istilah lain autonomy adalah salah satu aspek kepribadian yang melahirkan perilaku mandiri seseorang. Perilaku mandiri merupakan aspek kepribadian yang amat penting dan sangat diperlukan individu dalam berprestasi dan menghadapi tugas-tugas dalam kehidupan sehari-hari.

\section{Kreatifitas}

$$
\text { Pengertian kreatifitas }
$$

menurut Kamus Besar Bahasa Indonesia adalah memiliki daya cipta; memiliki kemampuan untuk menciptakan; daya cipta pekerjaan yang menghendaki kecerdasan dan imajinasi. Jadi dapat diartikan bahwa kreatifitas merupakan kemampuan menciptakan pengetahuan/teknik/cara baru dalam menyelesaikan pekerjaan dan mampu mengemukakan ide-ide baru yang digunakan dapat mengatasi permasalahan. Menurut Nur'aeni (2008) kreatifitas adalah kemampuan untuk mencipta/berkreasi. Tidak ada satupun pernyataan yang dapat diterima secara umum mengenai mengapa suatu kreasi timbul. Kreatifitas sering dianggap terdiri dari 2 unsur, Pertama: Kefasihan yang ditunjukkan oleh kemampuan menghasilkan sejumlah besar gagasan pemecahan masalah secara lancar dan cepat. Kedua: Keluwesan yang pada umumnya mengacu pada kemampuan untuk menemukan gagasan yang berbeda-beda dan luar biasa untuk memecahkan suatu masalah.

Kemampuan akuntansi dasar dan penguasaan teknologi informasi

Kemampuan akuntansi dasar dan penguasaan teknologi informasi Pada umumnya kemampuan akuntansi dasar adalah kemampuan terkait penguasaan prinsip-prinsip dasar akuntansi seperti kemampuan menjurnal, memposting ke buku besar, membuat neraca lajur hingga tersusunnya laporan keuangan. Sedangkan kemampuan terkait penguasaan teknologi informasi secara garis besar adalah kemampuan menggunakan perangkat teknologi informasi. Kemampuan ini sangat dibutuhkan dalam dunia kerja, dengan kata lain 'melek' teknologi informasi, sehingga dapat mengakses informasi yang dibutuhkan, menggunakan informasi untuk keperluantertentu, dan kemampuan beradaptasi dengan sistem yang digunakan di perusahaan.

\section{METODE PENELITIAN}

\section{Lokasi dan Waktu Penelitian}

Lokasi penelitian adalah di Jawa Tengah yaitu Kota Semarang, Kota Kudus, Kab Kendal, Kota Salatiga, Kab Ungaran. yang menjadi tujuan utama tempat PKL mahasiswa D III Akuntansi Polines. Penelitian ini dilakukan dalam waktu 5 bulan (Desember - Maret 2015 dan 2016).

\section{Populasi dan Sampel}

Populasi dalam penelitian ini adalah seluruh perusahaan/industri yang merupakan tempat PKL mahasiswa Program Studi D III 
Akuntansi Polines yang berlokasi mayoritas di Kota Semarang, dan Kudus. Karakteristik industri yang dijadikan populasi antara lain: (1) merupakan perusahaan/instansi yang berskala menengah dan besar sehingga cukup representatif untuk dijadikan sebagai tujuan PKL mahasiswa, (2) memiliki bagian akuntansi atau bagian keuangan atau bagian lain yang relevan dengan bidang ilmu akuntansi, (3) memiliki struktur organisasi yang jelas, (4) merupakan perusahaan yang dimiliki oleh swasta (berbentuk PT), BUMN, BUMD, instansi pemerintah/ Pemerintah Daerah (Pemda), Perbankan, Koperasi dan distributor besar/Cabang Utama dari perusahaan besar, (5) Perusahaan bergerak dalam bidang jasa, dagang, manufaktur.

Untuk mahasiswa, yang dijadikan sebagai populasi adalah seluruh mahasiswa semester 5 Program Studi D III Akuntansi Polines angkatan 2013 dan 2014 yang melaksanakan PKL dalam periode 2015 dan 2016 sehingga jumlahnya mencapai 200 orang. Metode pemilihan sampel yang digunakan adalah metode sensus, yaitu penyebaran kuesioner dilakukan pada semua populasi. Industri yang dijadikan sampel penelitian dipilih dengan menggunakan metode purposive sampling sesuai dengan karakteristik yang disebutkan di atas.

Metode Pengumpulan Data dan Instrumen Penelitian

Data yang dikumpulkan dalam penelitian ini merupakan data primer yang dikumpulkan dengan menggunakan instrumen berupa kuesioner. Kuesioner berisikan serangkaian daftar pertanyaan yang disusun secara terstruktur sesuai dengan 5 kelompok kemampuan yang ingin diteliti, yaitu:

a) Bagian pertama berisikan 5 pertanyaan yang bertujuan untuk menilai kemampuan berkomunikasi mahasiswa. b) Bagian kedua berisikan 7 pertanyaan yang bertujuan untuk menilai kemampuan kerjasama (teamwork) mahasiswa baik dengan rekan kerja dalam satu tim dalam departemen yang sama, departemen yang berbeda, serta kepemimpinan dalam tim.

c) Bagian ketiga berisikan 6 pertanyaan untuk menilai kemampuan kemandirian mahasiswa yang dilihat dari kemampuan menyelesaikan pekerjaan secara mandiri, inisiatif dalam mencari solusi atas masalah yang dihadapi dalam menyelesaikan pekerjaan, termasuk softskill terkait perilaku dan sikap dalam bekerja.

d) Bagian keempat berisikan pertanyaan untuk menilai kreatifitas mahasiswa seperti mengemukakan ide baru dan mengaplikasikan teknik baru dalam pekerjaan.

e) Bagian kelima memuat pertanyaan mengenai kompetensi mahasiswa yang dinilai dari kompetensi ilmu akuntansi dasar dan keterampilan terkait teknologi informasi, seperti kemampuan mengoperasikan software aplikasi Ms Office, mengetik cepat, kemampuan beradaptasi dengan sistem informasi yang digunakan dalam perusahaan tempat PKL.

Kuesioner yang dikirimkan disertai dengan surat permohonan dan penjelasan tentang tujuan diberikannya kuesioner kepada industri responden. Kuesioner juga dilengkapi dengan petunjuk sederhana tapi jelas sehingga memudahkan responden memahami pertanyaan kuesioner dan memberikan jawaban.Kuesioner yang digunakan adalah kuesioner langsung yang disebarkan oleh mahasiswa yang akan melaksanakan PKL. Distribusi kuesioner dapat dilakukan dengan mudah, karena kuesioner diberikan kepada mahasiswa semester V Program Studi D III Akuntansi Polines. Kuesioner ini secara tidak langsung menjadi salah satu media penilaian bagi industri dan Jurusan 
Akuntansi terhadap kemampuan mahasiswa selama melaksanakan PKL.

\section{Definisi Operasional, Metode dan}

\section{Skala Pengukuran Variabel}

Variabel kualitas mahasiswa selama PKL diukur dengan menilai kemampuan mereka dalam lima kelompok kompetensi yaitu (1) kemampuan

kemampuan

kemandirian

kemampuan

penguasaan

Defenisi operasional dari masingmasing kemampuan tersebut dijelaskan dan diukur melalui indikator seperti pada Tabel 1

Tabel 1 Variabel, Definisi Operasional, Indikator dan Skala Pengukuran

\begin{tabular}{|c|c|c|c|c|}
\hline $\begin{array}{l}\mathrm{N} \\
\mathrm{o}\end{array}$ & Variabel & $\begin{array}{c}\text { Definisi } \\
\text { Operasional }\end{array}$ & Indikator & $\begin{array}{c}\text { Skala } \\
\text { Pengukura } \\
\text { n }\end{array}$ \\
\hline 1 & $\begin{array}{l}\text { Kemampuan } \\
\text { berkomunikas } \\
\text { i }\end{array}$ & $\begin{array}{l}\text { Kemampuan dalam } \\
\text { berkomunikasi baik } \\
\text { lisan maupun } \\
\text { tulisan } \\
\text { dalam bahasa } \\
\text { inggris dan bahasa } \\
\text { Indonesia }\end{array}$ & $\begin{array}{l}\text { Mahasiswa mampu: } \\
\text { 1)Menyampaikan } \\
\text { informasi secara } \\
\text { lisanataupun tulisan } \\
\text { (laporan) kepada } \\
\text { atasan/pemberi kerja. } \\
\text { 2) Berkomunikasi } \\
\text { secara lisan dan tulisan } \\
\text { dalam bahasa inggris. } \\
\text { 3) Memahami dan } \\
\text { menulis surat bisnis } \\
\text { dalam bahasa Indonesia } \\
\text { dan bahasan inggris } \\
\text { 4) Mengkomunikasikan } \\
\text { ide baru dalam } \\
\text { pekerjaan } \\
\text { 5) Kemampuan } \\
\text { menerjemahkan } \\
\text { instruksi kerja }\end{array}$ & $\begin{array}{c}\text { Linkert } \\
1-5\end{array}$ \\
\hline 2 & $\begin{array}{l}\text { Kemampuan } \\
\text { bekerjasama } \\
\text { dalam tim } \\
\text { (teamwork) }\end{array}$ & $\begin{array}{l}\text { Kemampuan } \\
\text { bekerjasama dalam } \\
\text { tim baik dalam } \\
\text { posisi sebagai } \\
\text { anggota ataupun } \\
\text { sebagai ketua tim }\end{array}$ & $\begin{array}{l}\text { Mahasiswa memiliki: } \\
\text { 1) Kemampuan } \\
\text { kerjasama dalam satu } \\
\text { tim kerja } \\
\text { 2) Kemampuan } \\
\text { kerjasama dengan rekan } \\
\text { sekerja/sedepartemen } \\
\text { 3) Kemampuan } \\
\text { kerjasama dengan rekan } \\
\text { sekerja di } \\
\text { bagian/departemen lain } \\
\text { 4)Kemampuan } \\
\text { mengkoordinasikan } \\
\text { sebuah tugas kepada } \\
\text { tim (sebagai } \\
\text { koordinator) Kemampuan } \\
\text { 5) m dugas } \\
\text { menyelesaikan diberikan dan } \\
\text { yang dang } \\
\text { bertanggung jawab atas } \\
\text { hasilnya }\end{array}$ & $\begin{array}{c}\text { Likert } \\
1-5\end{array}$ \\
\hline 3 & $\begin{array}{l}\text { Kemampuan } \\
\text { kemandirian }\end{array}$ & $\begin{array}{l}\text { Kemampuan untuk } \\
\text { menyelesaikan }\end{array}$ & $\begin{array}{l}\text { Mahasiswa memiliki: } \\
\text { 1) Kemampuan }\end{array}$ & $\begin{array}{l}\text { Likert } \\
1-5\end{array}$ \\
\hline
\end{tabular}




\begin{tabular}{|c|c|c|c|c|}
\hline & & $\begin{array}{l}\text { tugas } \\
\text { mandiri }\end{array}$ & $\begin{array}{l}\text { menyelesaikan tugas } \\
\text { yang diberikan tanpa } \\
\text { supervisi atasan } \\
\text { 2) Kemampuan } \\
\text { menyelesaikan tugas } \\
\text { yang diberikan secara } \\
\text { mandiri } \\
\text { 3)Kemampuan } \\
\text { memecahkan masalah } \\
\text { dengan insiatif sendiri. } \\
\text { 4) Memiliki rasa } \\
\text { percaya diri dan } \\
\text { berperilaku baik dan } \\
\text { sopan. }\end{array}$ & \\
\hline 4 & Kreatifitas & $\begin{array}{l}\text { Memiliki } \\
\text { alternatif/cara/tekn } \\
\text { i } \\
\text { k/solusi baru dalam } \\
\text { bekerja. }\end{array}$ & $\begin{array}{l}\text { Mahasiswa memiliki } \\
\text { kemampuan: } \\
\text { 1) Kemampuan } \\
\text { mengaplikasikan } \\
\text { pengetahuan/teknik/car } \\
\text { a baru dalam } \\
\text { menyelesaikan } \\
\text { pekerjaan, } \\
\text { 2) Kemampuan } \\
\text { mengemukakan ide } \\
\text { baru dalam } \\
\text { menyelesaikan masalah }\end{array}$ & $\begin{array}{c}\text { Likert } \\
1-5\end{array}$ \\
\hline 5 & $\begin{array}{l}\text { Kemampuan } \\
\text { dasar } \\
\text { akuntansi dan } \\
\text { penguasaan } \\
\text { teknologi } \\
\text { informasi }\end{array}$ & $\begin{array}{l}\text { Kompetensi dalam } \\
\text { penerapan prinsip- } \\
\text { prinsip dasar } \\
\text { akuntansi dan } \\
\text { penguasaan } \\
\text { software aplikasi } \\
\text { perkantorandan } \\
\text { kemampuan } \\
\text { beradaptasi dengan } \\
\text { sistem yang ada } \\
\text { dalam perusahaan. }\end{array}$ & $\begin{array}{l}\text { Mahasiswa memiliki } \\
\text { kemampuan: } \\
\text { 1)Menerapkan } \\
\text { kemampuan akuntansi } \\
\text { dasar dalam } \\
\text { menyelesaikan } \\
\text { pekerjaan } \\
\text { 2) Menggunakan } \\
\text { aplikasi Ms Office } \\
\text { 3) Menggunakan } \\
\text { aplikasi Soft ware } \\
\text { Akuntansi seperti } \\
\text { Myob/Zahir } \\
\text { 4)Mengoperasikan alat- } \\
\text { alat perkantoran } \\
\text { modern. Beradaptasi dengan } \\
\text { 5) Berang digunakan } \\
\text { sistem yang } \\
\text { perusahaan. }\end{array}$ & $\begin{array}{c}\text { Likert } \\
1-5\end{array}$ \\
\hline
\end{tabular}

Model dan Teknik Analisis Data 1). Uji kualitas Data (uji validitas dan uji realiabilitas kuesioner)

Uji validitas dan reliabilitas atas kuesioner tidak dilakukan lagi pada penelitian ini karena kuesioner yang digunakan adalah kuesioner yang sudah lulus uji validitas dan realibilitas pada pengujian beberapa tahun sebelumnya. Kuesioner yang digunakan sebelumnya di ujicobakan ke beberapa mahasiswa untuk di uji validitas dan reliabilitas.

2). Teknik Analisis Data

Data yang diperoleh diolah dengan menggunakan statistik deskriptif, dengan menggunakan data nilai rata-rata per item dalam 
pertanyaan dalam kelompok penilaian yang diuji .

\section{HASIL DAN PEMBAHASAN}

Profil Resaponden

Jumlah kuesioner yang disebarkan kepada responden industri adalah sebanyak 160 unit. Kuesioner tersebut didistribusikan melalui mahasiswa semester 5

Program Studi D-III Akuntansi Politeknik Negeri Semarang yang akan melaksanakan PKL. Dari 160 kuesioner yang diisi tersebut, 9 kuesioner tidak bisa diolah karena tidak diisi lengkap oleh industri, sedangkan sisanya sebanyak 151 layak diolah. Berikut adalah data distribusi kuesioner.

Tabel 1

Dsitribusi Kuesioner Menurut Lokasi perusahaan

\begin{tabular}{|c|c|c|c|c|c|c|}
\hline \multirow{2}{*}{ Provinsi/Kota/Kab } & \multicolumn{2}{|c|}{2015} & \multicolumn{2}{|c|}{2016} & \multirow{2}{*}{$\begin{array}{l}\text { Total } 2 \\
\text { Tahun }\end{array}$} & \multirow{2}{*}{$\begin{array}{l}\text { Rata- } \\
\text { Rata } 2 \\
\text { Tahun }\end{array}$} \\
\hline & Unit & $\%$ & Unit & $\%$ & & \\
\hline Semarang & 42 & $58.3 \%$ & 48 & $60.8 \%$ & 90 & 45 \\
\hline Kudus & 12 & $16.7 \%$ & 13 & $16.5 \%$ & 25 & 12.5 \\
\hline Salatiga & 4 & $5.6 \%$ & 3 & $3.8 \%$ & 7 & 3.5 \\
\hline Surakarta & 4 & $5.6 \%$ & 4 & $5.1 \%$ & 8 & 4 \\
\hline Tegal & 6 & $8.3 \%$ & 8 & $10.1 \%$ & 14 & 7 \\
\hline Jawa Timur & 4 & $5.6 \%$ & 3 & $3.8 \%$ & 7 & 3.5 \\
\hline & 72 & & 79 & & 151 & \\
\hline
\end{tabular}

Sumber ; pengolahan data primer tahun 2016 Industri yang menjadi responden dalam penelitian ini merupakan industri yang menjadi tempat pelaksanaan PKL mahasiswa. Pada umumnya industri yang menjadi responden mayoritas berada di Jawa tengah, karena industri di Jawa Tengah lebih diminati oleh mayoritas mahasiswa akuntansi dengan alasan kemudahan akses dan pertimbangan biaya yang lebih murah daripada memilih PKL di luar Jawa Tengah. Responden terbesar Di propinsi Jawa tengah adalah industri yang berada di

Tabel 2

Semarang, yang merupakan salah satu tujuan PKL mahasiswa karena karena sebagai ibukota Jawa Tengah, Semarang merupakan pusat industri dan lokasi mayoritas perusahaan besar berada, sehingga lebih banyak pilihan yang tersedia disamping lebih besarnya kesempatan untuk mendapatkan pengetahuan, pengalaman kerja dan wawasan yang lebih luas. Profil industri yang menjadi responden dikategorikan menjadi 5 kelompok seperti terlihat dalam tabel 2 di bawah

menurut Jenis Industri Responden

\begin{tabular}{|c|c|c|c|c|c|c|}
\hline \multirow{2}{*}{ Perusahaan/Instansi } & \multicolumn{2}{|c|}{2015} & \multicolumn{2}{|c|}{2016} & \multirow{2}{*}{$\begin{array}{l}\text { Total } 2 \\
\text { Tahun }\end{array}$} & \multirow{2}{*}{$\begin{array}{l}\text { Rata- }^{-} \\
\text {Rata } 2 \\
\text { Tahun }\end{array}$} \\
\hline & Unit & $\%$ & Unit & $\%$ & & \\
\hline Swasta & 29 & $40.3 \%$ & 33 & $41.8 \%$ & 62 & 31 \\
\hline Pemerintah Pusat & 11 & $15.3 \%$ & 12 & $15.2 \%$ & 23 & 11.5 \\
\hline Pemerintah Daerah & 21 & $29.2 \%$ & 23 & $29.1 \%$ & 44 & 22 \\
\hline BUMN & 4 & $5.6 \%$ & 4 & $5.1 \%$ & 8 & 4 \\
\hline \multirow[t]{2}{*}{ BUMD } & 6 & $8.3 \%$ & 8 & $10.1 \%$ & 14 & 7 \\
\hline & 71 & & 80 & & 151 & \\
\hline
\end{tabular}

Sumber ; pengolahan data primer tahun 2016 
Responden terbesar dalam penelitian ini adalah industri swasta seperti PT. Nasmoco, industi jasa, instansi pemerintah daerah dan pusat seperti Kantor Pelayanan Pajak (KPP) Pratama, Pemerintah Daerah, Kantor Pusat Perbendaharaan Negara (KPPN) di berbagai wilayah di Jawa Tengah. Jumlah kuesioner yang disebarkan kepada industri responden yang merupakan Badan Usaha Milik Negara (BUMN) di wilayah jawa tengah, seperti PT. PLN (Persero), Perum Pegadaian, PT. Jaminan Sosial Tenaga Kerja (Jamsostek), PT. Taspen, PT. Askes juga cukup banyak. Sedangkan untuk Badan Usaha Milik Daerah masih terbatas pada industri yang berada di Kota Semarang seperti PDAM Tirta moedal. Demikian pula halnya dengan industri perbankan dan perusahaan swasta masih terbatas pada perusahaan yang ada di Jawa Tengah saja.

\section{Hasil Penelitian}

Kualitas mahasiswa PKL diukur melalui lima kelompok kompetensi yaitu (1) kemampuan berkomunikasi (2) kemampuan bekerjasama (teamwork) (3) kemampuan kemandirian (4) kreatifitas (5) kemampuan dasar akuntansi dan penguasaan teknologi informasi. Hasil pengolahan data menunjukkan bahwa secara ratarata kemampuan mahasiswa yang dinilai selama mereka melakukan PKL di industri untuk 5 kelompok kompetensi di atas adalah baik seperti yang disajikan dalam tabel 3

Tabel 3

Rerata Nilai per Komponen Kemampuan

\begin{tabular}{|c|c|c|c|}
\hline Rata-rata Per komponen & 2015 & 2016 & $\begin{array}{l}\text { Rata-Rata } 2 \\
\text { Tahun }\end{array}$ \\
\hline Komunikasi & 4.11 & 4.12 & 4.12 \\
\hline Kerjasama & 4.39 & 4.35 & 4.37 \\
\hline Kemandirian & 4.36 & 4.34 & 4.35 \\
\hline Kreatifitas & 4.23 & 4.21 & 4.22 \\
\hline $\begin{array}{l}\text { Kemampuan dasar AK dan Penguasaan } \\
\text { TI }\end{array}$ & 3.97 & 4.05 & 4.01 \\
\hline
\end{tabular}

Sumber ; pengolahan data primer tahun 2016

Dari 5 kelompok kompetensi dengan rekan sekerja dalam satu yang dinilai oleh industri, kemampuan bekerjasama (teamwork) merupakan kompetensi yang mendapatkan rerata nilai tertinggi $(4,38)$, diikuti oleh kemandirian $(4,35), \quad$ kreatifitas $\quad(4,22)$, kemampuan berkomunikasi $(4,12)$ dan kemampuan dasar akuntansi dan penguasaan teknologi informasi $(4,01)$. Kemampuan bekerja tim (teamwork) mahasiswa akuntansi merupakan kemampuan yang mendapatkan nilai rerata tertinggi karena kemampuan mahasiswa dalam memahami dan melaksanakan tugas yang diberikan juga baik $(4,50)$ sehingga tidak sulit bagi mereka untuk bekerjasama dalam satu tim, baik departemen yang sama $(4,51)$ ataupun departemen yang berbeda $(4,45)$ yang didukung dengan pemahaman yang baik tentang tujuan organisasi/perusahaan $(4,43)$.

Hasilnya adalah mereka mampu menyelesaikan pekerjaan tepat waktu dan mempertanggung jawabkan hasilnya dengan baik $(4,32)$ sehingga dapat dipercayakan tugas sebagai koordinator tim $(4,30)$. Kemandirian mahasiswa dalam menyelesaikan tugas yang diberikan juga dinilai baik oleh industri. Mahasiswa dinilai memiliki rasa percaya diri yang tinggi dalam menjalankan tugas $(4,59)$ sehingga mereka dapat mengerjakan tugas secara mandiri dengan baik $(4,41)$ 
tanpa perlu pengawasan dari supervisor $(4,33)$ dan berinisiatif mencari solusi dalam menyelesaikan masalah yang dihadapi dalam pekerjaan $(4,32)$ dengan tetap mempertahankan perilaku yang baik dan sopan (4,32) selama melaksanakan tugas yang diberikan.

Kreatifitas mahasiswa dalam bekerja merupakan kemampuan yang mendapatkan rerata nilai cukup tinggi dari industri (4.22). Kemampuan mahasiswa dalam menggunakan cara/teknik cara baru dalam menyelesaikan pekerjaan $(4,34)$ serta mengemukakan ide baru dalam menyelesaikan pekerjaan dinilai baik oleh industri $(4,11)$. Kemampuan berkomunikasi mahasiswa secara umum dinilai baik oleh industri $(4,12)$, meskipun secara rerata nilai untuk kemampuan ini belum sebaik kemampuan softskills lainnya. Mahasiswa akuntansi dinilai memiliki kemampuan yang baik dalam memahami instruksi tugas yang diberikan tanpa perlu dijelaskan secara lebih detil oleh pemberi tugas $(4,41)$. Mahasiswa akuntansi juga memiliki kemampuan yang baik dalam menyampaikan informasi secara lisan atau tulisan (laporan) kepada atasan (4,38). Hal ini terlihat dari kemampuan berkomunikasi lisan, seperti mengemukakan ide baru $(4,02)$ yang diikuti oleh kemampuan menyampaikan informasi secara tertulis (menulis surat bisnis atau menyusun laporan) baik dalam bahasa Indonesia atau bahasa inggris $(3,89)$.

Kemampuan akuntansi dasar dan penguasaan teknologi informasi secara rata-rata terkategori baik $(4,07)$. Secara terpisah kemampuan penguasaan teknologi informasi memiliki rerata lebih tinggi $(4,16)$ dibandingkan dengan kemampuan akuntansi dasar $(4,07)$. Penguasaan teknologi informasi tersebut ditunjukkan oleh kemampuan penguasaan Ms-Office $(4,48)$, kemampuan mengetik cepat (manual ataupun elektrik) (4,33), kemampuan beradaptasi cepat dengan system yang ada dalam perusahaan $(4,29)$ yang didukung oleh kemampuan mengoperasikan alat perkantoran modern $(3,86)$ dan alatalat untuk presentasi $(3,73)$.Kemampuan dasar akuntansi mahasiswa terkait penguasaan prinsip-prinsip akuntansi dasar dalam menyelesaikan tugas mendapatkan nilai rerata yang juga masuk dalam kategori baik $(4,07)$, walaupun rerata skornya lebih Rendah dibanding kemampuan lain. Kemampuan akuntansi, relatif tidak terlalu banyak terpakai oleh mahasiswa di lapangan karena pada umumnya mahasiswa akuntansi yang melaksanakan PKL belum mendapatkan kepercayaan penuh dari industri untuk mengakses data sistem informasi akuntansi atau proses pelaporan keuangan perusahaan.

Pada umumnya jenis pekerjaan yang diberikan kepada mahasiswa sewaktu melaksanakan PKL lebih banyak berupa pekerjaan administratif yang bersifat rutin yang sudah tersistem dengan baik dan pekerjaan rutin operasional. Mahasiswa belum dilibatkan pada level pemberian input untuk pengambilan keputusan. Meskipun secara aggregate, rerata nilai untuk kemampuan akuntansi tidak setinggi kemampuan lain, namun khusus untuk mahasiswa yang melaksanakan PKL.

\section{SIMPULAN}

Secara umum, kemampuan softskills dan hardskills mahasiswa akuntansi Polines yang dinilai oleh industri selama mereka melaksanakan PKL adalah baik, dengan rerata nilai 400 berada dalam range 4,0-4,5.Kemampuan mahasiswa tersebut diranking dari kemampuan yang mendapatkan rerata nilai tertinggi ke terendah yaitu: (1) kemampuan bekerjasama (teamwork), (2) kemandirian, (3) kreatifitas, (4) kemampuan komunikasi, dan (5) kemampuan 
dasar akuntansi dan penguasaan teknologi informasi. Meskipun secara umum terkategori baik, hardskills mahasiswa terkait kemampuan dasar akuntansi masih harus ditingkatkan karena kemampuan ini merupakan kemampuan vital yang diperlukan dalam dunia kerja. Penelitian berikutnya diharapkan dapat mengembangkan komponen penilaian yang lebih luas dari lima kelompok kemampuan yang digunakan dalam penelitian ini dengan wilayah penelitian yang lebih luas.

\section{DAFTAR PUSTAKA}

Budi Presetya dan Karnowohadi, (2011). Model magang terencana guna penguatan kompetensi lulusan pada Prodi Admisnitrasi Bisnis. Jurnal Teknis.

Bovee, C.L., Thill, John., (2007) Komunikasi Bisnis, Edisi 8, Jilid I, Penerbit PT.Indexs.

Bhattacharyya,E., M Nordin, S., dan Salleh, R.,(2009) Internship Students' Workplace Communication Skills: Workplace Practices And University Preparation. Conference for Industry and Education Collaboration, (February 4-6), Orlando, Florida.

Guffey, M.E., Rhodes, K., Rogin, P., (2005) Business Communicatin: Process \& Product, Edisi 4, Penerbit Salemba Empat

Kamus Besar Bahasa Indonesia, http://kamusbahasaindonesia.or $\mathrm{g}$

Lilik, S., 2008, Meningkatkan Motivasi Berprestasi, Kemandirian, dan Penyesuaian Diri Karyawan, PAEDAGOGIA, Jilid 11, Nomor 1, Februari 2008, halaman $22-32$.

M. Alisuf Sabri, (2010), Pengantar psikologi umum dan perkembangan, Pedoman ilmu jaya. Jakarta.

Muhamad, R., et.al. (2009). Undergraduate Internship Attachment in Accounting: The Interns Perspective, International Education Studies. November.

Murnomo. Agus, (2010), Empat Langkah Strategis

Membangun Kualitas

Pendidikan Vokasi dan

Kejuruan di Indonesia,

Lembaran Ilmu Kependidikan Edisi April 2010.

Nur'aeni, (2008), Ada Apa Dengan Kreatifitas?, Islamadina, Vol.VII, No.3, September 2008:74-84, ISSN:1412-4777

Purwanto, Joko. (2006), Komunikasi Bisnis, Edisi 3, Penerbit Erlangga.

Republika online, Maret 2013, Tingkatkan Kemampuan Komunikasi, LP3i, http://www.republika.co.id/berit a/pendidikan/lp3i, diunduh Jumat 15 Maret 2013

Undang Undang No.12 Tahun 2012 tentang Perguruan Tinggi Wijanarka. B.S., (2012), Sosok Ideal Lulusan Pendidikan Vokasi Indonesia Genarasi 2045, Paper Kanospi 72012.

Tutik Dwi Karyanti, et al. (2011), Eksperimentasi perapan model magang kerja industry untuk peningkatan kompetensi mahasiswa Jurusan Akuntansi.

Yossi Septriani, Zahara dan Zalida Afni. (2013) Respon Industri Terhadap Kualitas mahasiswa selama Praktek Kerja Lapangan Studi Kasus pada Program Studi DIII Akuntansi Politeknik Negeri Padang. SNAV II, Bali. 